\author{
Aleksandra JADACH-SEPIOŁO \\ Dr, Zakład Miasta Innowacyjnego, Instytut Finansów Korporacji i Inwestycji, Szkoła Główna Handlowa w Warszawie \\ a.jadachsepiolo@gmail.com
}

\title{
ZAKRES PRZESTRZENNY LOKALNYCH SYSTEMÓW OSADNICZYCH JAKO CZYNNIK KSZTAŁTUJĄCY METODYKE, DIAGNOZY SPOŁECZNO-EKONOMICZNEJ W PROGRAMACH REWITALIZACJI
}

\begin{abstract}
Abstrakt: Zmiany społeczne i gospodarcze, których doświadczają gminy w ostatnich latach sprawiają, że wiele lokalnych systemów osadniczych ulega stopniowej erozji w najsłabszych punktach układów osadniczych. W przypadku lokalnych systemów osadniczych, zamkniętych obszarem administracyjnym jednej gminy, w programie rewitalizacji można wykorzystać pełen potencjał gminy, jednak konieczność uchwycenia zróżnicowania wewnątrzmiejskiego powoduje powstanie dylematów metodycznych związanych z zakresem przestrzennym diagnozy społeczno-ekonomicznej przeprowadzanej na potrzeby programów rewitalizacji. Celem artykułu jest przedstawienie wniosków dotyczących wyboru sposobu podziału obszaru analizy w związku ze specyfiką lokalnego systemu osadniczego.

Słowa kluczowe: programy rewitalizacji, delimitacja obszarów rewitalizacji, diagnoza społeczno-ekonomiczna.

\section{SPATIAL SCOPE OF LOCAL SETTLEMENT SYSTEMS AS A FACTOR FOR DESIGNING METHODOLOGY OF SOCIO-ECONOMIC DIAGNOSIS IN THE URBAN REGENERATION PROGRAMS}

Abstract: Social changes experienced by municipalities in recent years result in a gradual erosion of the weakest points of settlement systems. In the case of local settlement systems, closed in the administrative borders of one community, urban regeneration programs, the full potential of the community can be used, however, the necessity to grasp the diversity of the site creates methodological dilemmas related to the scope of spatial socio-economic diagnosis carried out for the purpose of revitalization programs. The aim of this article was to present proposals regarding the choice of the method of analysis in relation to the specific local settlement system.

Keywords: urban regeneration programs, delimitation of regeneration areas, socio-economic diagnosis.
\end{abstract}

\section{WPROWADZENIE}

Zgodnie z definicją wprowadzoną przez W. Maika, lokalny system osadniczy jest zbiorem jednostek osadniczych powiązanych funkcjonalnie poprzez aktywność codzienną ich mieszkańców (Maik 1968). Powiązania te nie ograniczają się jedynie do sfery przestrzennej, nie mniejsze znaczenie mają związki gospodarcze i społeczne. O sile powiązań wewnątrzlokalnych systemów osadniczych decydują ich endogeniczne potencjały oraz zdolności do wzmacniania związków funkcjonalnych pomiędzy mieszkańcami w konkretnej przestrzeni (Maik 1976, cyt. za: Wójcik 2012, s. 11).

Zmiany społeczne (w tym demograficzne) i gospodarcze, których doświadczają gminy w ostatnich latach, sprawiają, że wiele lokalnych systemów osadniczych ulega stopniowej erozji w najsłabszych punktach układów osadniczych. Odpowiedzią na wyzwania z niej wynikające jest rewitalizacja, definiowana jako proces „wyprowadzania ze stanu kryzysowego obszarów zdegradowanych, prowadzony w sposób kompleksowy, poprzez zintegrowane działania na rzecz lokalnej społeczności, przestrzeni i gospodarki, skoncentrowane terytorialnie, prowadzone przez interesariuszy rewitalizacji na podstawie gminnego programu rewitalizacji”. Zgodnie z nowym podejściem opisanym $\mathrm{w}$ „Wytycznych w zakresie rewitalizacji w programach operacyjnych na lata 2014-2020" (2016) niezbędnym wstępem do prowadzenia działań rewitalizacyjnych jest opracowanie programu. Wstępem do niego jest diagnoza skali i rodzaju zjawisk kryzysowych, a analizą obejmowana jest cała gmina. Prowadzone badania pozwalają zarówno dzięki analizie ilościowej, jak i jakościowej poznać zróżnicowanie problemów i potencjałów gminy. Diagnoza ta najdokładniej opisuje teren wybrany ze względu na kumulację zjawisk kryzysowych, ale także występowanie tam czynników istotnych dla rozwoju lokalnego (art. 10 ust. 1 UoR). Dzięki temu sporządzane programy rewitalizacji wskazują drogę do wyprowadzenia obszarów zdegradowanych 
z kryzysu za pomocą potencjałów występujących na tych obszarach bądź (w uzasadnionych przypadkach) w innych częściach gminy.

Celem autorki artykułu było przedstawienie wniosków dotyczących wyboru sposobu podziału terenu analizy w związku ze specyfiką lokalnego systemu osadniczego. W przypadku takich systemów, zamkniętych obszarem administracyjnym jednej gminy w programie rewitalizacji można wykorzystać pełen potencjał gminy, jednak konieczność uchwycenia zróżnicowania wewnątrzmiejskiego powoduje powstanie dylematów metodycznych związanych z zakresem przestrzennym diagnozy społeczno-ekonomicznej, przeprowadzanej na potrzeby programów rewitalizacji.

\section{WYZNACZENIE OBSZARU REWITALIZACJI}

Działaniem poprzedzającym programowanie procesu rewitalizacji jest wyznaczenie terenu koncentracji negatywnych zjawisk w przestrzeni miast, czyli tzw. obszaru zdegradowanego. Zgodnie z definicją ustawową jest to obszar „znajdujący się w stanie kryzysowym z powodu koncentracji negatywnych zjawisk społecznych, w szczególności bezrobocia, ubóstwa, przestępczości, niskiego poziomu edukacji lub kapitału społecznego, a także niewystarczającego poziomu uczestnictwa w życiu publicznym i kulturalnym [...] w przypadku występowania na nim ponadto co najmniej jednego z następujących negatywnych zjawisk gospodarczych [...] lub środowiskowych [...] lub przestrzenno-funkcjonalnych [...] lub technicznych"2. Delimitacja obszaru zdegradowanego powinna być uzasadniona danymi ilościowymi, w razie potrzeby uzupełnionymi wynikami badań jakościowych (Jadach-Sepioło, Jeżak, Kłosowski 2015, s. 13-19). Obszar zdegradowany może pokrywać nawet znaczną powierzchnię gminy, jeśli np. na duży obszar koncentracji różnorodnych negatywnych zjawisk społecznych nakładają się w różnych miejscach skoncentrowane problemy gospodarcze, techniczne lub środowiskowe. Z badań wynika, że objęcie zbyt dużego terenu działaniami rewitalizacyjnymi obniża ich skuteczność, ponieważ zbytnio rozprasza środki (BMVBS/BBR 2007, s. 21-28). W UoR wprowadzono więc limity obszaru rewitalizacji, a więc „obszar obejmujący całość lub część obszaru zdegradowanego, cechujący się szczególną koncentracją negatywnych zjawisk, o których mowa w art. 9 ust. 1, na którym z uwagi na istotne znaczenie dla rozwoju lokalnego gmina zamierza prowadzić rewitalizację"3. Zgodnie z art. 10 ust. 2 UoR, teren ten nie może przekraczać 20\% powierzchni gminy, ani nie może go zamieszkiwać więcej, niż 30\% jej mieszkańców.

Przechodząc od wyznaczenia obszaru zdegradowanego do wyboru obszaru rewitalizacji należy, obok natężenia zjawisk kryzysowych, przeanalizować także potencjał terenu do odnowy, tj. charakter lokalnych zasobów ${ }^{4}$. Zasięg tego terenu powinien zostać poddany konsultacjom społecznym ${ }^{5}$, a jego wytyczenie (zgodnie z wymogami ustawowymi) wiąże się $\mathrm{z}$ przyjęciem odrębnej uchwały, będącej aktem prawa miejscowego ${ }^{6}$.

Delimitacja obszaru rewitalizacji jest więc pracochłonnym procesem, który (zanim się zakończy) obejmuje:

- zebranie danych odzwierciedlających z jak największą dokładnością zjawiska (pozytywne i negatywne) występujące w gminie;

- wyznaczenie wartości wskaźników obrazujących negatywne zjawiska w sferze społecznej i w pozostałych analizowanych sferach;

- przyjęcie kryteriów oceny występowania zjawisk negatywnych w poszczególnych sferach;

- wyznaczenie granic obszaru zdegradowanego;

- identyfikacja czynników endogenicznych odzwierciedlających potencjał obszaru do odnowy.

$\mathrm{Na}$ każdym z wymienionych etapów konieczne jest dokonywanie rozstrzygnięć metodologicznych, które przekładają się na wynik analizy. Przesądzający wpływ na zakres obszaru rewitalizacji mogą mieć: wybór metody agregacji danych, dobór wskaźników oraz wyznaczenie kryteriów, na podstawie których podejmowana jest decyzja, czy w danym miejscu (jednostce przestrzennej, osiedlu, kwartale, ulicy itp.) występuje negatywne zjawisko, a następnie, czy występuje kumulacja negatywnych zjawisk. Niniejszy artykuł dotyczy pierwszego z wymienionych problemów - wyboru metody agregacji danych.

\section{OKREŚLENIE SPOSOBU ANALIZY ROZKŁADU PRZESTRZENNEGO BADANYCH ZJAWISK}

Jednym z pierwszych pytań, na które odpowiedzieć powinien zespół badawczy stojący przed problemem wyznaczenia obszaru zdegradowanego w rozumieniu art. 9 ust. 1 UoR, jest określenie sposobu wizualizacji rozkładu przestrzennego analizowanych zjawisk. Dwa podstawowe podejścia to podział na jednostki pseudo- 
naturalne (Parysek 1982, cyt. za: Jarczewski, Jeżak 2010, s. 22) oraz na jednostki sztuczne (modularne).

Istotą pierwszego podziału jest możliwość wyodrębnienia jednostek względnie homogenicznych morfologicznie, powiązanych funkcjonalnie i społecznie. Podział na jednostki pseudonaturalne został już dokonany $\mathrm{w}$ polskich miastach, wraz $\mathrm{z}$ wyodrębnieniem obwodów i rejonów spisowych. W części współistnieje on z innymi podziałami, np. na jednostki pomocnicze gminy bądź jednostki strukturalne (urbanistyczne), określone w studiach uwarunkowań i kierunków zagospodarowania przestrzennego (Jarczewski 2010, s. 2223). W związku z tym podziały takie nakładają się na siebie i swoistą trudność może stanowić wybór jednego z nich. Do rzadkości należą miasta, gdzie można zastosować do analiz delimitacyjnych dokładnie jeden $\mathrm{z}$ istniejących podziałów na jednostki pseudonaturalne. Najczęściej zespół badawczy stoi przed problemem wyznaczenia ich granic. Pomocne mogą być:

- „istniejące i historyczne granice dzielnic samorządowych;

- jednostki GUS (obwody spisowe i obręby statystyczne);

- kataster nieruchomości;

- wszystkie dostępne mapy miasta (historyczne i topograficzne);

- numeryczny model terenu;

- struktura tkanki miejskiej;

- wyniki badań literatury i inne” („Wytyczne...” 2015, s. 19).

Wynikiem prac analitycznych służących wydzieleniu jednostek pseudonaturalnych jest podział dostosowany do powiązań funkcjonalnych, społecznych oraz homogeniczności morfologicznej. W przypadku rozbieżności między granicami obwodów spisowych a wyznaczonymi jednostkami zaleca się wnioskowanie do GUS o dokonanie korekty granic tych obwodów. Dzięki temu zbieranie danych przy okazji aktualizacji programu rewitalizacji czy monitorowaniu zmian na terenach zdegradowanych i obszarach rewitalizacji będzie ułatwione.

Zastosowanie podejścia opartego na jednostkach pseudonaturalnych prowadzi do uzyskania podziału zupełnego, tj. cały obszar gminy zawrze się w wyznaczonych jednostkach.

Rozwiązaniem alternatywnym jest zastosowanie jednostek sztucznych (modularnych) (Jeżak, Cholewiński 2010, s. 67). Podziału tego dokonuje się za pomocą techniki analizy przestrzennej GIS, zwanej tesselacją (parkietażem) ${ }^{7}$. „Wykorzystanie pól geometrycz- nych wymaga pracochłonnego przypisania do każdego z nich konkretnych danych, za to pozwala na uzyskanie pełnej porównywalności przedstawionych na mapie obszarów” („Program rewitalizacji Łodzi...” 2016, s. 21). Dzięki zastosowaniu parkietażu można otrzymać rozkład badanego zjawiska w wyznaczonej siatce analitycznej (np. kwadraty, sześciokąty). Dzięki takiemu zabiegowi możliwa jest analiza badanych zjawisk z przypisaniem do konkretnej lokalizacji, bez rozproszenia wynikającego ze zróżnicowanej wielkości jednostek pseudonaturalnych. Pola niezamieszkałe nie są analizowane, chociaż, gdy ludności w danym polu jest bardzo niewiele, wyniki są zniekształcone $\mathrm{i} w$ interpretacji należy zawsze zestawiać je z liczbą ludności. Uzyskane dane są więc dużo bardziej precyzyjne. Wadą tego podejścia jest konieczność dostępu do dokładnych danych według punktów adresowych. Każdy inny poziom agregacji danych spowoduje zniekształcenie obrazu analizowanych zjawisk i w konsekwencji nieścisłości w ich interpretacji. Trudny jest także moment przejścia z jednostek sztucznych na naturalne granice najczęściej ulice. Analizy prowadzone przy zastosowaniu siatki analitycznej nie są zazwyczaj transparentne dla mieszkańców i innych interesariuszy procesu rewitalizacji, dlatego na etapie wyznaczania granic obszaru zdegradowanego i obszaru rewitalizacji zespół badawczy powinien posługiwać się już granicami w postaci ulic.

\section{LOKALNY SYSTEM OSADNICZY - SPECYFIKA GMINY MIEJSKIEJ}

W przypadku gminy miejskiej istotne znaczenie ma jej wielkość. W dużych miastach jednostki pseudonaturalne nie są jednorodne pod względem sposobu użytkowania terenu i realizowanych $\mathrm{w}$ nich funkcji. Dodatkowo nakłada się na siebie wiele podziałów, począwszy od statystycznych, przez geodezyjne i urbanistyczne (SUiKZP), po historyczne. W związku z tym rozwiązaniem metodologicznym, pozwalającym na uniknięcie tworzenia kolejnego podziału lub arbitralnego wyboru jednego $\mathrm{z}$ dotychczasowych, jest zastosowanie jednostek sztucznych. Przykładem takiego podejścia może być Łódź, gdzie wprost stwierdzono, uzasadniając wybór podejścia: „podział miasta na jednostki zawsze opierałby się na jakichś wstępnych założeniach (w tym często założeniach nieujawnionych wprost, a nawet przyjętych podświadomie). Wobec tego sam podział do pewnego stopnia determinowałby przyszły 


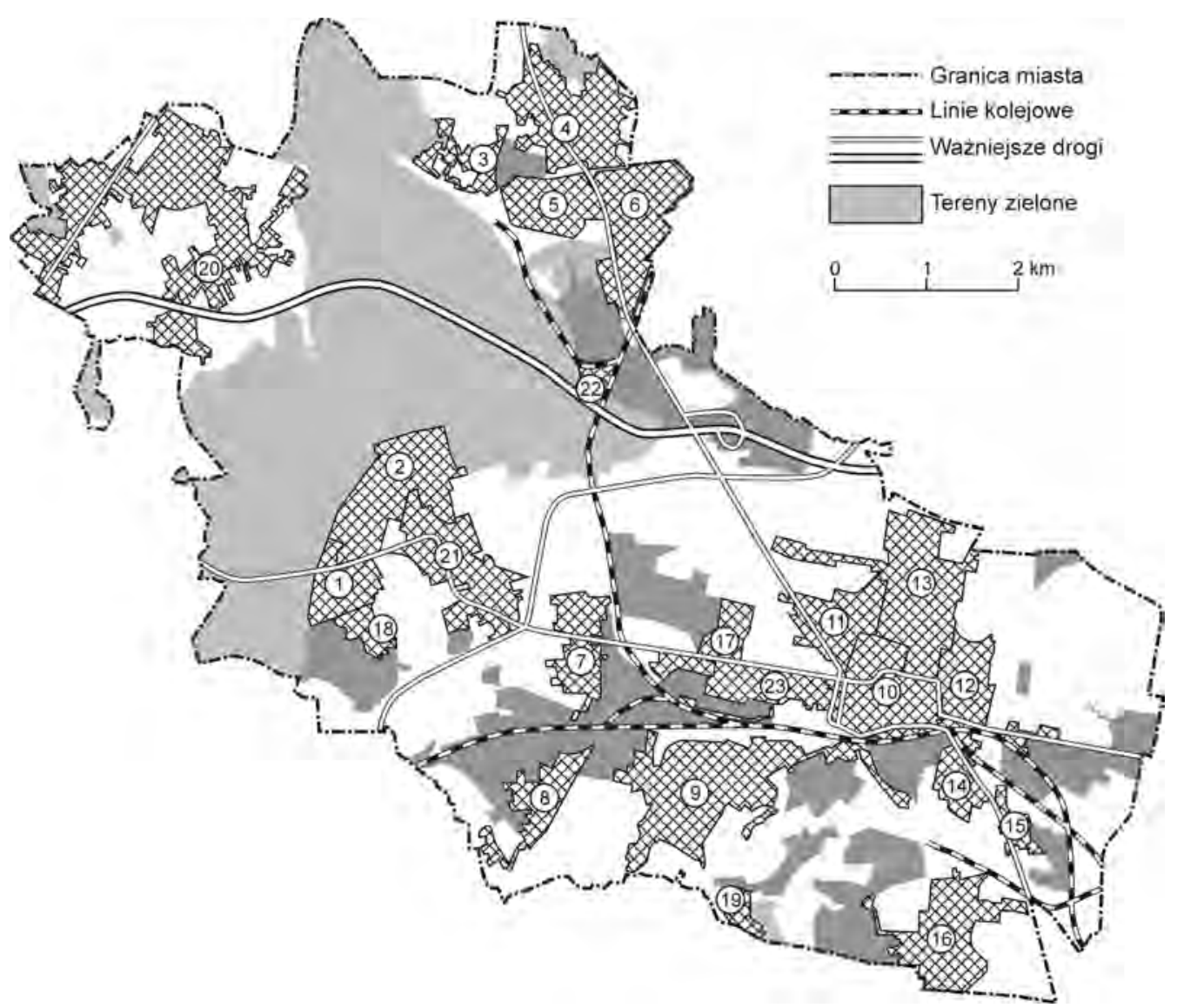

Rys. 1. Wydzielenie jednostek mieszkalnictwa w Bytomiu na potrzeby delimitacji obszaru zdegradowanego i obszaru rewitalizacji Źródło: W. Jarczewski, A. Gajda, A. Matuszko (2016, s. 12)

wynik diagnozy, co stałoby w pewnej sprzeczności z wymogiem bezstronności diagnozy” („Program rewitalizacji Łodzi” 2016, s. 21). Efektem było zastosowanie siatki heksagonalnej o oczku 10 ha pokrywającej całe miasto w granicach administracyjnych.

Opisane rozwiązanie sprawdza się $\mathrm{w}$ miastach o zwartej strukturze. W takiej sytuacji najczęściej nie ma możliwości wydzielenia terenów niezamieszkanych o cechach opisanych w art. 10 ust. 3 UoR. Zgodnie z przywołanym tu zapisem, tereny poprzemysłowe (np. poportowe i powydobywcze), powojskowe i pokolejowe, na których z powodu braku mieszkańców nie można stwierdzić negatywnych zjawisk w sferze społecznej, są często dotknięte innymi problemami w sferze gospodarczej, środowiskowej, technicznej lub przestrzenno-funkcjonalnej. Sprzężenie tych problemów powoduje, że nie tylko nie służą one lokalnej społeczności, lecz stanowią istotną barierę dla jej rozwoju. Interwencja na tych terenach może przyczynić się do przeciwdziałania negatywnym zjawiskom społecznym, które zostały zidentyfikowane w diagnozie.
W miastach o zróżnicowanej strukturze przestrzennej i wyraźnie wyodrębnionych jednostkach mieszkaniowych, którym towarzyszą jednostki o innym charakterze, wyznaczenie niezamieszkanych terenów poprzemysłowych staje się niezbędne, choćby z powodu konieczności spełnienia wymogów ustawowych. W takim przypadku do wyznaczania jednostek zurbanizowanych wykorzystywana jest np. metoda klasyfikacji terenów miejskich sformułowana przez S. Liszewskiego (1978). Badaniu podlegają funkcje terenu, a także charakter zabudowy i sposób użytkowania gruntu. Posługując się metodyką S. Liszewskiego, W. Jarczewski rekomenduje, aby wydzielać odrębne jednostki dla:

- terenów zieleni i rekreacji,

- użytków rolnych,

- wód,

- lasów,

- nieużytków,

- terenów o funkcjach produkcyjnych (poza niewielkimi zakładami wewnątrz osiedli), 
- dużych centrów handlowych,

- kompleksów biurowych,

- części terenów komunikacyjnych (np. torów lub bocznic) („Wytyczne...” 2015, s. 24).

$\mathrm{W}$ takim podejściu wyznacza się $\mathrm{w}$ granicach gminy tzw. obszary mieszkalnictwa wraz z powiązanymi z nimi najbardziej podstawowymi składnikami otoczenia. Na rys. 1 przedstawiono przykładowy rezultat dla Bytomia.

Dzięki wydzieleniu tych zamieszkałych jednostek możliwe jest ograniczenie powierzchni analizowanych obszarów, co ma znaczenie wobec limitów nałożonych UoR, istotnych zwłaszcza z punktu widzenia włączenia niezamieszkałych terenów poprzemysłowych. Jednocześnie analizy statystyczne prowadzone $\mathrm{w}$ jednostkach nie są obarczone błędem wynikającym z rozproszenia danych. W analogiczny sposób, tj. biorąc pod uwagę homogeniczne funkcje i morfologię danego obszaru poprzemysłowego, wyznacza się jednostki obejmujące te tereny. Uzyskujemy wskazanie zarówno mieszkaniowych, jak i niezamieszkanych obszarów, których ożywienie jest istotne z punktu widzenia rozwoju miasta.

Przedstawione korzyści z wyznaczania tak ściśle wykrojonych zurbanizowanych jednostek nie zawsze jednak rekompensują wady tego podejścia, które nie są widoczne podczas prowadzonej delimitacji, wpływają natomiast na sam proces rewitalizacji. Ograniczenie obszaru rewitalizacji jedynie do terenów zamieszkanych powoduje, że część terenów funkcjonalnie z nimi powiązanych nie może być miejscem lokalizacji projektów. Co prawda zarówno wytyczne krajowe („Wytyczne..." 2015), jak i UoR zezwalają na prowadzenie działań rewitalizacyjnych poza obszarami rewitalizacji, jednak na podstawie uwag do ocenianych obecnie (sierpnia 2016 r.) programów rewitalizacji („Wytyczne..." 2016) można stwierdzić, że bardzo rzadko dopuszczana jest taka możliwość. W związku z tym wydzielenie na etapie podziału miasta na jednostki terenów zielonych, nieużytków lub kompleksów biurowo-handlowych może powodować trwałe pozostawienie ich poza granicami obszarów wsparcia, niezależnie od realnych powiązań funkcjonalnych i potrzeb społeczności lokalnej.

W mniejszych gminach miejskich (rys. 2) możliwe jest więc przeprowadzenie zupełnego podziału ich powierzchni, co daje pewność niepomijania powiązań funkcjonalnych $\mathrm{w}$ ramach wyznaczonych jednostek. Krytyka takiego podejścia odwołuje się do wyżej przytoczonych argumentów, a głównie do ograniczonej homogeniczności tak wyznaczonych jednostek.

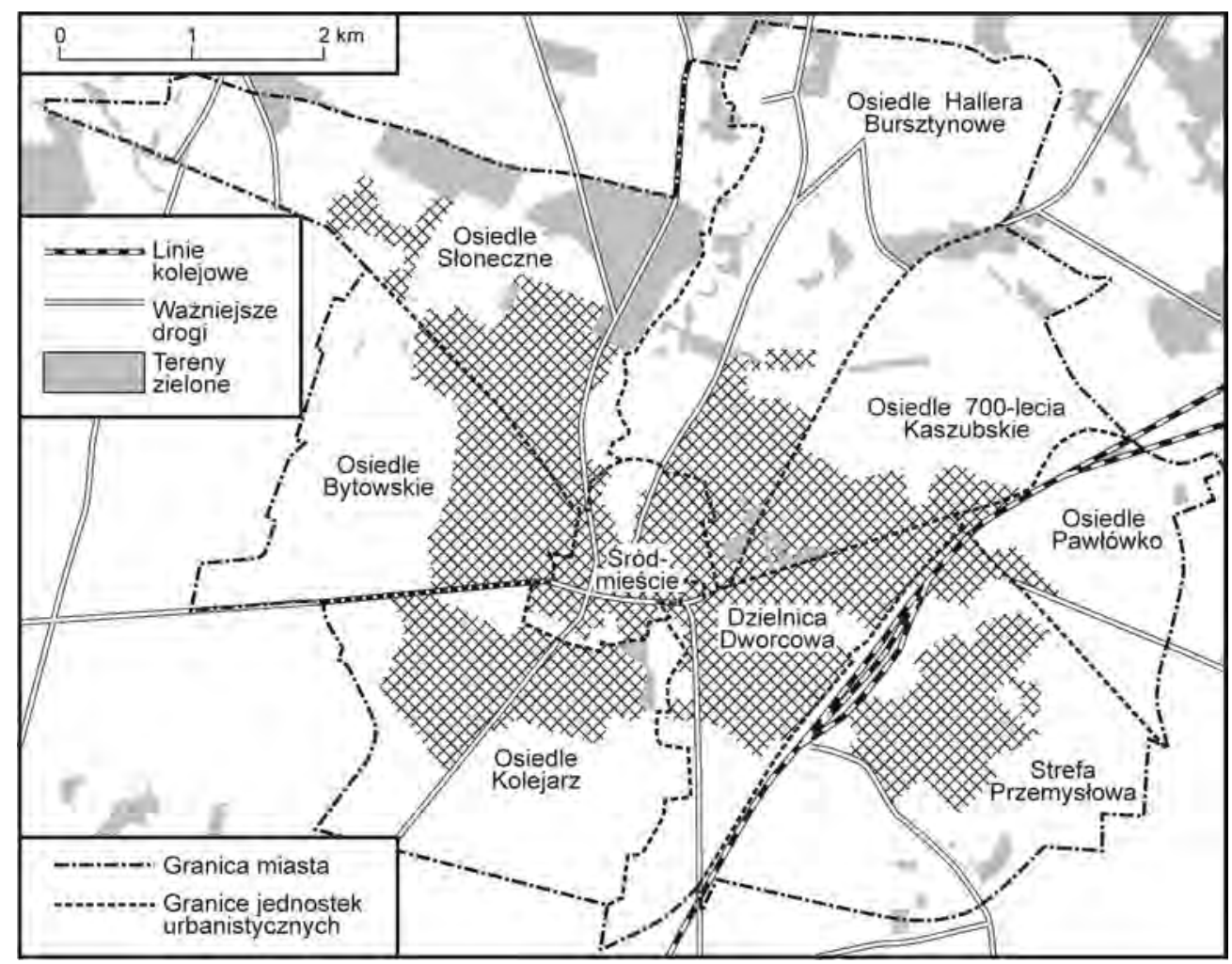

Rys. 2. Podział Chojnic na miejskie jednostki urbanistyczne na potrzeby delimitacji obszaru zdegradowanego

Źródło: A. Jadach-Sepioło i in. (2015, s. 23), oprac. map M. Huculak 
Przy prowadzeniu analiz na poziomie tak wyznaczonych jednostek zakłada się, że ze względu na jednorodność morfologiczną i powiązania funkcjonalne nie powinny one podlegać kolejnym podziałom, więc wybór obszaru zdegradowanego sprowadza się do wyznaczenia sumy miejskich jednostek urbanistycznych, w których koncentrują się zjawiska negatywne. Problemem może być zbyt duża rozległość jednostek, jednak w takiej sytuacji łatwiej jest przedyskutować ze społecznością lokalną rozmieszczenie negatywnych zjawisk w jednostkach, gdzie zidentyfikowano ich największą kumulację. Korzyścią jest pogłębiona analiza problemów w jednostkach wyznaczonych z poszanowaniem powiązań funkcjonalnych, a wadą - wydłużenie procesu analitycznego.

\section{PODSUMOWANIE}

W artykule przedstawiono regulacyjne uwarunkowania prowadzenia diagnozy obszaru zdegradowanego na potrzeby opracowania programu rewitalizacji. Na tym tle określono podstawowe dylematy metodyczne, które wynikają z konieczności analiz zróżnicowania wewnątrzmiejskiego negatywnych zjawisk w poszczególnych sferach (społecznej, gospodarczej, technicznej, środowiskowej i funkcjonalno-przestrzennej). Jednym z podstawowych dylematów jest wybór sposobu podziału analizowanego lokalnego systemu osadniczego na potrzeby prowadzonej diagnozy. Wyróżniono dwa główne podejścia, bazujące na jednostkach pseudonaturalnych oraz sztucznych. W obu przypadkach przedstawiono zalety wymienionych podejść oraz możliwości ich dopasowania do specyfiki miasta. W przypadku jednostek pseudonaturalnych rozważano:

- wyodrębnienie $\mathrm{w}$ granicach administracyjnych miasta jednostek zurbanizowanych i przeprowadzenie analiz w ich granicach, połączone $\mathrm{w}$ razie potrzeby $\mathrm{z}$ analizą niezamieszkanych obszarów poprzemysłowych;

- podział zupełny miasta na jednostki pokrywające całą powierzchnię miasta, uwzględniający istniejące powiązania funkcjonalne i społeczne oraz nieprzecinający granic, np. z użytkowanymi przez lokalną społeczność otwartymi terenami zielonymi.

Jako alternatywę dla tych podziałów zaprezentowano analizę w jednostkach sztucznych, która - dzięki oderwaniu od często subiektywnego przebiegu granic między jednostkami - pozwala zobiektywizować diag- nozę i jednocześnie wesprzeć wyznaczanie obszaru, na którym koncentrują się negatywne zjawiska bez zakłóceń wywołanych uśrednieniami dla jednostek.

Wybór odpowiedniego podejścia jest uwarunkowany specyfiką konkretnego miasta i powinien tylko do niej być dostosowany. Jedynie w przypadku miast zwartych zdecydowano się na jednoznaczną rekomendację. Sugerowane jest zastosowanie jednostek sztucznych, ale nie oznacza to mniejszej użyteczności analiz prowadzonych $\mathrm{w}$ jednostkach pseudonaturalnych. Wybór zależy od wielkości miasta, dostępności danych, liczby alternatywnych podziałów na jednostki pseudonaturalne oraz możliwości obiektywizacji podziału. Często też decyzje o wyborze danego podejścia uwarunkowane są koniecznością wejścia na z góry wyznaczony obszar, jednak ten problem naukowej analizie umyka.

\section{PRZYPISY}

${ }^{1}$ Art. 2 ust. 1 ustawy z dnia 9 października 2015 r. o rewitalizacji (Dz. U. 2015, poz. 1777), zwanej dalej UoR.

${ }^{2}$ Art. 9 ust. 1 UoR; pominięto fragmenty przedstawiające przykładowe zjawiska ilustrujące degradację w poszczególnych sferach.

${ }^{3}$ Art. 10 ust. 1 UoR.

${ }^{4}$ Lokalne czynniki endogeniczne to zasoby społeczne, gospodarcze i przestrzenne determinujące zdolność obszaru do rozwoju (Kuciński 2008).

${ }^{5}$ Art. 5-6 UoR.

${ }^{6}$ Art. 8 ust. 1 UoR.

7 Parkietaż to pokrycie płaszczyzny wielokątami przylegającymi i niezachodzącymi na siebie (Coxeter 1967, s. 69). Z punktu widzenia analiz przestrzennych stosowane są parkietaże platońskie (regularne foremne), tj. takie, w których w wierzchołku spotykają się jednorodne foremne figury geometryczne.

\section{BIBLIOGRAFIA}

BMVBS/BBR, 2007, Integrated Urban Development - A Prerequisite for Urban Sustainability in Europe, BBR-Online-Publikation 09/2007, Bonn.

Coxeter H.S.M., 1967, Wstęp do geometrii dawnej i nowej, PWN, Warszawa.

Jadach-Sepioło A., Jeżak J., Kłosowski W., 2015, Od obszaru zdegradowanego do obszaru rewitalizacji, Instytut Rozwoju Miast na zlecenie Ministerstwa Infrastruktury i Rozwoju, Warszawa.

Jadach-Sepioło A., Kozłowska B., Sikorska P., Brzycki A., 2015, Raport dotyczący delimitacji obszarów zdegradowanych miasta Chojnice. Materiał badawczy $i$ wprowadzający do „Lokalnego programu rewitalizacji masta Chojnice”, Chojnice.

Jarczewski W., 2010, Audyt miejski z wykorzystaniem jednostek urbanistycznych, [w:] W. Jarczewski, J. Jeżak, System monitorowania rewitalizacji, ser. „Rewitalizacja Miast Polskich”, 11, Instytut Rozwoju Miast, Kraków, s. 21-56. 
Jarczewski W., Jeżak J., 2010, System monitorowania rewitalizacji, ser. „Rewitalizacja Miast Polskich”, 11, Instytut Rozwoju Miast, Kraków.

Jarczewski W., Gajda A., Matuszko A., 2016, Raport z delimitacji obszaru zdegradowanego i obszaru rewitalizacji Bytomia, Instytut Rozwoju Miast, Kraków; zał. do Uchwały XXIII/300/16 Rady Miejskiej w Bytomiu z 29 marca 2016 r. w sprawie wyznaczenia obszaru zdegradowanego i obszaru rewitalizacji.

Jeżak J., Cholewiński P., 2010, Audyt miejski z wykorzystaniem jednostek modularnych, [w:] W. Jarczewski, J. Jeżak, System monitorowania rewitalizacji, ser. „Rewitalizacja Miast Polskich”, 11, Instytut Rozwoju Miast, Kraków, s. 65-84.

Kuciński K., 2008, Miasto w procesie dezindustrializacji, [w:] W. Morawski, A. Zawistowski (red.), Stare okręgi przemysłowe. Dylematy industrializacji $i$ dezindustrializacji, Szkoła Główna Handlowa w Warszawie, Warszawa, s. 161-179.

Liszewski S., 1978, Tereny miejskie. Podział i klasyfikacja, „Acta Universitis Lodziensis. Folia Geographica Socio-Oeconomica", 15.

Maik W., 1968, Niektóre problemy badań nad układami osadniczymi, „Czasopismo Geograficzne”, 39 (2).
„Program rewitalizacji Łodzi 2026+. Gminny program rewitalizacji”, wersja do konsultacji społecznych, Łódź lipiec 2016.

Ustawa z 9 października 2015 r. o rewitalizacji (Dz. U. 2015, poz. 1777).

Wójcik M., 2012, Zespół i lokalny system osadniczy - geneza i ewolucja koncepcji w polskiej geografii społeczno-ekonomicznej, „Acta Universitatis Lodziensis. Folia Geographica Socio-Oeconomica", 12, s. 3-18.

„Wytyczne dotyczące programowania przedsięwzięć rewitalizacyjnych w celu ubiegania się o środki finansowe w ramach Regionalnego Programu Operacyjnego Województwa Pomorskiego na lata 2014-2020" (Załącznik nr 13 do Zasad wdrażania RPO WP 2014-2020, Uchwała nr 628/54/15 Zarządu Województwa Pomorskiego z 30 czerwca 2015 r. w sprawie przyjęcia Zasad wdrażania RPO WP 2014-2020, aktualizacja: maj 2016 r.).

„Wytyczne w zakresie rewitalizacji w programach operacyjnych na lata 2014-2020, z 2 sierpnia 2016 r.", Ministerstwo Rozwoju, Warszawa.

Artykuł wpłynął:

8 czerwca 2016

Zaakceptowano do druku:

2 września 2016 